\title{
СРАВНЕНИЕ СПОСОБОВ ПОДГОТОВКИ СУЛЬФИДНЫХ МЕДНО-НИКЕЛЕВЫХ РУД К РЕНТГЕНОФЛУОРЕСЦЕНТНОМУ АНАЛИЗУ С ПОЛНЫМ ВНЕШНИМ ОТРАЖЕНИЕМ
}

Жиличева А.Н. ${ }^{1,2}$, Пашкова Г.В. ${ }^{1,2}$, Пантеева С.В. ${ }^{1}$, Чубаров В.М. ${ }^{3}$, Марфин А.Е. ${ }^{1}$

${ }^{1}$ ФГБУН Институт земной коры СО РАН, Иркутск, Россия

${ }^{2}$ ФГБОУ ВО Иркутский государственный университет, Иркутск, Россия

${ }^{3}$ ФББУН Институт геохимии им. А.П. Виноградова СО РАН, Иркутск, Россия

pashkova.gv@yandex.ru

DOI: 10.26902/ASFE-11_104

Для определения основных элементов ( $\mathrm{S}, \mathrm{Fe}, \mathrm{Cu}, \mathrm{Ni}, \mathrm{Se})$ в сульфидных медно-никелевых рудах использовали метод рентгенофлуоресцентного анализа с полным внешним отражением (TXRF). Объектами исследования были образцы с содержанием сульфидов от 10 до 90 \%, представленные как промышленно-бедными рудами и безрудными породами, так и массивными сульфидными рудами. Измерения выполняли на рентгеновском спектрометре с полным внешним отражением S2 PICOFOX (Bruker, Германия). Результаты TXRF были сопоставлены с результатами, полученными методами гравиметрии (S), атомноабсорбционного анализа $(\mathrm{Fe}, \mathrm{Ni}, \mathrm{Cu})$ и изотопного разбавления $(\mathrm{Se})$.

Рассмотрены разные варианты подготовки руд к TXRF: кислотное разложение (50 мг образца +2 мл $\mathrm{HNO}_{3}+5$ мл $\mathrm{HF}+1$ мл $\mathrm{HClO}_{4}$ ) и прямой анализ (приготовление суспензии - 20 мг порошка +5 мл 1\% раствора Triton X-100). В обоих случаях в качестве внутреннего стандарта добавляли раствор нитрата галлия и после перемешивания 10 мкл образца помещали на кварцевую подложку-отражатель и высушивали. Для каждого образца готовили пять независимых излучателей, каждый из которых измеряли три раза. Результаты обработали по схеме однофакторного дисперсионного анализа для разложения суммарной погрешности на составляющие, характеризующие воспроизводимость измерения аналитических линий и погрешность пробоподготовки. Суммарная погрешность (относительное стандартное отклонение (RSD)) измерения растворов после разложения не превышала 5 \%, однако при открытом кислотном разложении наблюдались потери серы и селена. Погрешности измерения суспензий значительно зависели от размера частиц порошка и достигали более 30 \%. Для устранения эффекта размера частиц на результаты TXRF анализа предложено использовать мокрое измельчение с использованием мельницы MM-400 (Retsch, Германия). 100 мг образца помещали в размольный стакан (10 мл), добавляли 20 г шариков из $\mathrm{ZrO}_{2}$ диаметром 1 мм и 100 мкл внутреннего стандарта Ga (1 г/л). Конечный раствор доводили до объема очищенной водой и измельчали в течение 10 мин при частоте 20 Гц. Размер частиц в исследуемых порошках контролировали методом лазерной дифракции, используя гранулометр «ANALYSETTE 22 NanoTec» (Fritsch GmbH, Германия). Применение мокрого измельчения позволило уменьшить размер частиц до 1-5 мкм. Это улучшило не только воспроизводимость результатов анализа (значения RSD в среднем не превышали 5\%), но и правильность при определении $\mathrm{S}, \mathrm{Fe}, \mathrm{Cu}, \mathrm{Ni}, \mathrm{Se}$ методом TXRF.

Работа выполнена с использованием оборудования Центров коллективного пользования «Геодинамика и геохронология» ИЗК СО РАН и «Изотопно-геохимических исследований» ИГХ СО РАН при финансовой поддержке гранта Правительства Российской Федеращии №075-15-2019-1883. 